\title{
El disulfiram supervisado es más eficaz en alcoholismo que la naltrexona o el acamprosato e incluso la psicoterapia: cómo funciona y por qué es importante
}

\author{
Supervised disulfiram is more effective in \\ alcoholism than naltrexone or acamprosate - or even \\ psychotherapy: how it works and why it matters
}

\author{
Colin Brewer \\ Research Director, The Stapleford Centre. \\ Enviar correspondencia a:
}

Colin Brewer. Research Director, The Stapleford Centre, London SW1W 9NP. England. mailto:cbrewer@doctors.net.uk

\section{RESUMEN}

Aunque hayan sido rechazados o ridiculizados por muchos médicos, por revisores de publicaciones y por autores de guías de tratamientos, los ensayos controlados aleatorios individuales (RCTs) y meta-análisis muestran claramente que la introducción de un tratamiento supervisado de disulfiram (TSD) en los programas de tratamiento del alcoholismo da sistemáticamente mejores resultados que si se incluye la naltrexona (NTX) o el acamprosato (ACP).

Los tamaños medios de los efectos para el NTX y para el ACP en alcoholismo son bajos -0.28 y 0.26 respectivamente, frente al 0.53 del TSD. Muchos de los estudios con NTX no incluyeron alcohólicos ambivalentes o severos (por ejemplo, infractores recurrentes alcohólicos). Aunque existen algunos estudios negativos con NTX y ACP, incluso en aquellos más fiables, todos los estudios sobre TSD en los que los pacientes recibieron realmente la medicación prevista tuvieron efectos positivos e, incluso muchas veces, muy positivos.

El abuso del consumo del alcohol es prácticamente desconocido entre los japoneses que son homocigóticos para la aldeido deshidrogenasa "ineficiente". El TSD actúa simplemente reproduciendo esta variante genética -normal, pero con una alta capacidad protectora- de una forma reversible. Este artículo revisa la literatura más reciente acerca del tema y analiza los factores ideológicos y financieros que contribuyen al escaso uso del TSD. La evidente superioridad deITSD debería convertirle en la primera opción de tratamiento para pacientes cuya situación es susceptible de empeorar rápidamente en caso de una recaída temprana. Aunque el tratamiento farmacológico es una prolongación de la relación terapéutica y no debe ser nunca un sustituto de ésta, muchos pacientes con respuesta positiva al TSD parecen necesitar muy poca intervención psicoterapéutica específica. Ello puede deberse al hecho de que el TSD actúa no sólo como un freno eficaz ante el consumo de alcohol, sino también como un potente reforzador del cambio cognitivo y de comportamiento.

Palabras clave: disulfiram, naltrexona, acamprosato, psicoterapia, aldehído deshidrogenasa, ALDH, alcoholismo, tratamiento.

\section{ABSTRACT}

Although neglected or derided by many clinicians, literature reviewers and producers of treatment guidelines, individual randomised controlled trials (RCTs) and meta-analyses show clearly that including supervised disulfiram treatment (SDT) in alcoholism treatment programmes consistently gives better outcomes than including naltrexone (NTX) or acamprosate (ACP).

Average effect sizes for NTX and ACP in alcoholism are small -0.28 and 0.26 respectively, against 0.53 for SDT. Many studies of NTX did not include severe or ambivalent alcoholics (eg recurrent alcoholic offenders). While there are several negative studies of NTX and ACP, even when compliance was good, all studies of SDT in which patients actually received the planned medication had positive and often very positive results.

Alcohol abuse is virtually unknown among Japanese who are homozygous for 'inefficient' aldehyde dehydrogenase. SDT simply reproduces this normal but highly protective genetic variant in a reversible manner. This paper reviews the latest literature and discusses the ideological and financial factors that contribute to SDT's under-use. The clear superiority of SDT should make it the first treatment choice for patients whose situation would rapidly become much worse if they had an early relapse. Though pharmacological treatment is an extension of the therapeutic relationship and not a substitute for it, many patients who respond to SDT seem to need very little specific psychotherapeutic intervention. This may be because SDT is not just an effective deterrent to drinking alcohol but also a powerful reinforcer of cognitive and behavioural change.

Key words: disulfiram, naltrexone, acamprosate, psychotherapy, aldehyde dehydrogenase, ALDH, alcoholism, treatment. 


\section{INTRODUCCIÓN: LA GENÉTICA DE LA SOBRIEDAD}

$\mathbf{S}$ i se hablara acerca de un grupo de adultos fácilmente identificables, no islámicos, que no conociera el consumo abusivo de alcohol - y nos referimos a que éste fuera de verdad desconocido y no sólo inusual o poco común-, probablemente se pensaría en un grupo pequeño, irrelevante desde un punto de vista clínico y con una determinada cultura o religión capaz de actuar como mecanismo social para reforzar la abstinencia o moderación del consumo. Algo similar a las comunidades amish de Nueva Inglaterra, por ejemplo. Lo más normal sería pensar, y con razón, que la existencia de tal grupo no ofrece ninguna explicación para ayudar a tratar a los alcohólicos que llaman a la puerta de nuestras clínicas porque, aunque se quisiera, cosa que seguramente no ocurre, sería imposible convertir a nuestros pacientes en devotos amish. Solamente los lectores con inclinaciones antropológicas podrían mostrar un atisbo de interés. Sin embargo, sí que existe un grupo en el que la ausencia de un consumo elevado de alcohol no se explica por factores culturales. De ellos podemos aprender mucho acerca de alternativas para mejorar los tratamientos que se ofrecen aquí y ahora.

Este grupo está formado por todos aquellos japoneses (y también por algunos de sus vecinos) que son homocigóticos para un gen que da una versión muy ineficiente de la encima aldehído deshidrogenasa $(A L D H)$, la cual media en una etapa importante en el metabolismo del alcohol, de acetaldehído a ácido acético. El grupo en cuestión representa en total un $8 \%$ de la población japonesa, lo que suma 9 millones de habitantes de un país donde el consumo del alcohol no sólo está establecido desde antiguo, sino que también se encuentra socialmente aceptado. En una muestra de 322 varones, trabajadores de la industria, un $9,6 \%$ de los que contaban con un ALDH normal eran consumidores abusivos de alcohol; sin embargo, no aparecía ninguno entre los homocigóticos para la ALDH "ineficiente" variante ALDH*2 y sólo un 4,2\% entre los heterocigóticos que lo habían heredado de sólo uno de sus progenitores (Sun et al. 2002). Esto equivalía a un problema crónico de bebida en un $8.4 \%$, $0 \%$ y $3.1 \%$ de la muestra respectivamente $(p<0.001)$. Existen otros estudios que confirman que el hecho de pertenecer a este grupo de homocigóticos ofrece una protección completa contra el alcoholismo o el abuso del alcohol, tal como conocemos estos términos. He preguntado en conferencias a varios expertos en alcoholismo de Japón acerca del tema y su única duda es una muy pequeña que discutiremos más tarde.

El grupo de homocigóticos japoneses del que hablamos no tiene, en general, objeciones morales o culturales ante la bebida una vez alcanzada la edad para consumir y muchos de ellos probablemente lamentan
INTRODUCTION: THE GENETICS OF SOBRIETY.

f you were told about an easily identifiable, nonIslamic group of adults in whom heavy drinking was unknown - and I mean unknown, not just unusual or relatively uncommon - you would probably assume that they were a small, clinically irrelevant group who all shared a culture or religion that had social mechanisms for enforcing abstinence or moderation. Something like the Amish communities of New England, perhaps. You would probably say, rightly, that the existence of such groups tells us nothing that helps us to treat the alcoholics who knock on our clinic doors, because we cannot turn them into devout Amish even if we wanted to, which most of us probably don't. Only anthropological readers might register a flicker of interest. However, there is one such group in whom the absence of heavy drinking is not explained by cultural factors and we can learn a lot from them about ways of improving treatment here and now.

This group is made up of all those people in Japan (and in some of its neighbours) who are homozygous for a gene which gives them a very inefficient version of the enzyme acetaldehyde dehydrogenase (ALDH) that mediates an important stage in alcohol metabolism, from acetaldehyde to acetic acid. They number about $8 \%$ of the Japanese population, so there are about 9 million of them in a country where alcohol use is long established and normal.

In a sample of 322 male factory workers, 9.6\% of those with normal ALDH were heavy drinkers but none in homozygotes for the 'inefficient' ALDH variant $\mathrm{ALDH}^{*} 2$ and only $4.2 \%$ of the heterozygotes inheriting it from only one parent (Sun et al 2002). That corresponded to definite problem drinking in $8.4 \%, 0 \%$ and $3.1 \%$ of the sample respectively $(p<0.001)$. Several other genetic studies confirm that homozygosity confers complete protection against alcoholism or alcohol abuse as we understand the terms. I have questioned several Japanese alcoholism experts at conferences about this matter and their only caveat is a very small one that I will discuss shortly.

These Japanese homozygotes generally have no moral or cultural objections to drinking when they reach drinking age and many of them probably regret their inability to take part in ordinary social drinking. Some of them would undoubtedly become problem drinkers were it not for one simple consequence of 
su incapacidad para poder participar del habitual consumo social de este producto. Algunos, sin duda, habrían llegado a tener problemas con la bebida, sino fuera por la simple respuesta de su estructura genética que tiene como consecuencia que su consumo, incluso en pequeñas cantidades, les haga sentirse enfermos, incrementándose los síntomas a medida que aumenta la cantidad que toman. Ello es debido a que, cuando beben, su ALDH*2 "ineficiente" produce una acumulación de acetaldehído que tiene como respuesta unos efectos desagradables, especialmente sofocos, dolores de cabeza y nauseas. Por ello este grupo no bebe alcohol o, si lo hace, lo toma en dosis de carácter simbólico con fines ceremoniales o gastronómicos como dar sabor a una salsa.

La importancia clínica de esta información, aparentemente secreta, es que describe con precisión los efectos farmacológicos y de comportamiento de los pacientes tratados con disulfiram. Todo lo que este producto hace es convertir a sus pacientes, de una manera voluntaria y reversible, en una buena imitación de japoneses homocigóticos para el ALDH*2, aunque la realidad muestra que su utilización no es tan eficiente como la que produce la naturaleza. Unos pocos pacientes no responden de manera significativa al tratamiento con disulfiram incluso a dosis elevadas (Brewer, 1984), pero estos casos son raros y, por otro lado, realmente no existe ningún medicamento que sea efectivo al $100 \%$. Mis fuentes japonesas me indican que se pueden encontrar algunos japoneses homocigóticos ALDH*2 con problemas psicológicos serios que intentan automedicarse con alcohol. Son en general pocos casos y, aunque sus intentos de beber pueden incrementar sus problemas, nunca consiguen consumir grandes cantidades de alcohol según los estándares normales de bebida.

\section{LA IMPORTANCIA DE LA SUPERVISION EN EL CONSUMO}

Lo expuesto hasta aquí debería ser una razón más que suficiente para concienciar a todos los que trabajan en el mundo del tratamiento contra el alcohol del potencial del disulfiram, especialmente en el caso del elevado, y muchas veces desmoralizante, número de pacientes que no responden a otros tratamientos. Sin embargo, existen tres consideraciones adicionales que indican que no considerar al disulfiram con la suficiente importancia dentro del menú de tratamientos significa que se está ofreciendo un servicio deficiente e incompleto. La primera de estas consideraciones, aunque importante, no es nueva. Existe una gran base evidencial desde los años setenta hasta nuestros días que muestra que cuando la administración del disulfiram es supervisada por profesionales de la salud, por familiares, colegas o por supervisores de vigilancia condicional, los tratamientos supervisados con disulfi- their genetic makeup, namely that drinking even quite small amounts of alcohol makes them feel ill and the more they drink, the worse they feel. That is because when they drink, their 'inefficient' ALDH ${ }^{*} 2$ causes an accumulation of acetaldehyde which has unpleasant effects, notably flushing, headache and nausea. Therefore they do not drink alcohol, or they drink it only in very small symbolic amounts for ceremonial purposes, or for gastronomic ones such as flavouring a sauce.

The clinical importance of this seemingly arcane information is that it accurately describes both the pharmacological and behavioural effects of treating patients with disulfiram. All that disulfiram does is to turn patients reversibly and voluntarily into a good imitation of Japanese ALDH*2 homozygotes, though it is not quite as efficient as nature. There are a few patients in whom even large doses of disulfiram do not significantly impair acetaldehyde breakdown (Brewer, 1984) but they are unusual and anyway, not many drugs are 100\% effective. Japanese informants tell me that there are also a few Japanese ALDH*2 homozygotes with troublesome psychological problems, who try to self-medicate with alcohol. They are very rare and although their attempts to drink may add to their problems, they never manage to consume large amounts by ordinary alcoholic standards.

\section{THE IMPORTANCE OF SUPERVISED CONSUMPTION.}

This background alone ought to make everyone in the world of alcoholism treatment aware of disulfiram's potential, especially for the large and often demoralising number of patients who do not respond to other treatments. However, three additional considerations mean that anyone who does not give disulfiram a prominent place in their treatment menu is providing a deficient and incomplete service. One of these additional considerations, though important, is not new. It is the large evidence-base from the mid-1970s onwards showing that when its administration is supervised by health professionals, family members, colleagues or probation staff, supervised disulfiram treatment (SDT) is an effective and often highly effective component of any multimodal approach to alcoholism. (Brewer 1992; Brewer et al 2000) Unfortunately, this extensive literature is 
ram (TSD) se convierten en un componente efectivo, $y$ muchas veces muy efectivo, dentro de cualquier enfoque multimodal frente al alcoholismo (Brewer 1992; Brewer et al 2000). Desgraciadamente, esta extensa literatura ha sido ampliamente ignorada o malinterpretada, incluso por los propios médicos. Los revisores de publicaciones muchas veces no tienen en cuenta la crucial distinción que existe entre el uso del disulfiram no supervisado, que suele tener una eficacia tan baja como la de un placebo, y el TSD. Algunos revisores mantienen erróneamente la efectividad de los implantes de disulfiram. Por supuesto que tienen una respuesta mejor que cuando no existen, pero no son más eficaces que los implantes de placebo porque, aunque como idea parecen útiles, no existe ningún modelo comercializado que dé los niveles necesarios de disulfiram o produzca una verdadera reacción farmacológica cuando se consume alcohol (Johnsen y Morland 1992). Muchos de los revisores siguen citando el amplio estudio esencialmente negativo que indica que el disulfiram no es eficaz o tiene sólo un eficacia marginal que fue recopilado por Fuller et al. (1986), incluso después de que él mismo haya aceptado en correspondencia publicada posteriormente (Fuller, 1987) la seria carencia que supuso la falta de una supervisión correcta de su consumo -aunque inicialmente se llevarán a cabo sesiones semanales de asesoramiento-.

\section{LA VUELTA DEL DISULFIRAM}

Una autoridad internacional en alcoholismo dedicó parte de un libro, por lo demás justo y equilibrado y dirigido tanto a médicos como al público general, a la supuesta falta de una buena evidencia de efectividad del disulfiram y a como esto podía implicar que su prescripción no era ética, a pesar de que sí se mencionaba a los homocigóticos japoneses (Edwards, 2000). Sin embargo, en enero del 2004, la revista de la que este autor es todavía editor en jefe publicó una editorial escrita por el mismo Fuller (Fuller y Gordis, 2004), apoyada por varios comentarios de importantes investigadores internacionales, donde se aceptaba que el TSD era realmente una tratamiento eficaz (Ehrenreich y Krampe 2004; Chick 2004.). Esta editorial tan oportuna, que invertía la información recibida hasta el momento, no podía explicarse por la aparición de evidencias nuevas o más convincentes, ya que, desde la aparición del libro, solamente se había publicado un pequeño estudio controlado sobre adolescentes (Niederhofer y Staffen, 2003).

La supervisión no consiste sólo en observar como el paciente introduce en su boca una tableta y la traga con un poco de agua. A no ser que se trate de pastillas fáciles de disolver en agua, un gran número de pacientes puede hacer creer que se que ha tragado sus pastillas y eludir el tratamiento escupiéndolas más tarde. Las personas al cargo de la supervisión deben tener en widely ignored or misinterpreted, even by medical commentators. Reviewers of the literature often fail to make the crucial distinction between unsupervised disulfiram, which is usually no more effective than placebo, and SDT. Some reviewers mistakenly claim that disulfiram implants are effective. They are certainly more effective than no implants but no more effective than placebo implants because although they sound like a useful idea, no commercially available model gives effective blood disulfiram levels or causes a true pharmacological reaction when alcohol is consumed. (Johnsen \& Morland 1992) Many reviewers cite the large and essentially negative RCT carried out by Fuller et al (1986) as evidence that disulfiram is ineffective or only marginally effective, even though Fuller himself later accepted in subsequent published correspondence (Fuller, 1987) that the lack of supervised consumption (despite weekly counselling sessions, initially) was a serious deficiency.

\section{THE DISULFIRAM REVIVAL.}

One international authority on alcoholism devoted part of an otherwise quite balanced book, aimed at both doctors and the public, to an alleged lack of good evidence for disulfiram's effectiveness and an implication that to prescribe it was unethical, even though he also mentioned the Japanese homozygotes (Edwards, 2000). However, in January 2004, the journal of which he is still editor-in-chief published an editorial partly written by Fuller himself (Fuller \& Gordis, 2004) supported by several internationally distinguished commentators, accepting that SDT was indeed an effective treatment (Ehrenreich \& Krampe 2004; Chick 2004.). This welcome editorial U-turn cannot have been due to new and more convincing evidence because only one additional small controlled study in adolescents (Niederhofer \& Staffen, 2003) had been published since the appearance of the book.

Supervision is not just a matter of seeing the patient put a tablet into his mouth and then swallow some water. Unless the tablets are dissolved or suspended in liquid, a significant number of patients will evade treatment by pretending to swallow it and then spitting it out later. Supervisers must also be aware that patients have been known to substitute other plain white tablets for disulfiram. 
cuenta también que algunos pacientes han llegado a sustituir al disulfiram por otras pastillas parecidas.

Es evidente que el disulfiram no es la única medicación útil contra el alcoholismo. El acamprosato está siendo utilizado desde hace ya unos años, aunque sólo recientemente en los Estados Unidos. También contamos con la naltrexona, aunque en los países donde se puede conseguir no está siempre oficialmente autorizado para tratar el abuso del alcohol y de opiáceos. Se espera con impaciencia el inminente lanzamiento de la primera licencia para el uso del preparado de naltrexona depot de efectos a largo plazo (Garbutt et al. 2005) con el convencimiento de que con la resolución del problema de que los pacientes tomen seguro la medicación esto dará buenos dividendos tanto a la comunidad de pacientes como a los fabricantes. Sin embargo, el tercer hecho fundamental es la aparición de los primeros resultados comparando el uso supervisado de disulfiram con alguna o ambas de estas alternativas; la realidad es que ninguna de ellas resiste la comparación, incluso en aquellos casos en los que su consumo también es supervisado. El primer estudio -a pequeña escala- mostró como el naltrexona no tenía un efecto muy válido en pacientes que abusaban tanto de alcohol como de cocaína, mientras que el TSD sí que reducía considerablemente el consumo de ambas drogas (Carroll y Ziedonis, 1993). Su eficacia fue confirmada por un estudio más amplio realizado en el año 1998 en el que, de una manera accidental e inesperada, se mostraba que el TSD era beneficioso a la hora de actuar contra el abuso de la cocaína, incluso cuando no existía el abuso de alcohol (Carroll et al., 1998).

\section{EL DISULFIRAM, MÁS EFECTIVO QUE LA PSICOTERAPIA.}

El estudio también comparaba varios tipos de psicoterapia - tratamiento cognitivo comportamental (TCC) y Facilitación en Doce Escalones (FDE)- con tratamientos clínicos convencionales (TCC) -por ejemplo, un grado mínimo de psicoterapia - apoyados con o sin TSD. (Carroll et al., 1998). Los sujetos asignados al TSD permanecieron más tiempo en el tratamiento que aquellos que no contaban con medicación (8.4 contra 5.8 semanas, $p<0.05)$. Es interesante observar como el componente de psicoterapia tenía un efecto poco significativo sobre la retención en el tratamiento y tampoco se encontraron diferencias importantes entre los dos tipos de psicoterapia analizados. "Los tamaños de efectos para el disulfiram comparados con el tratamiento sin medicación durante el periodo de abstinencia de la cocaína, el alcohol o ambos fueron respectivamente de $0.42,0.68$ y 0.46." En contraste, "los tamaños de efectos para la psicoterapia activa comparados con TCC durante el periodo de abstinencia fueron de 0.16 para la cocaína, 0.11 para el alcohol y 0.18 para ambos". El tamaño de efecto indica la contribución específica
Of course, disulfiram is not the only medication that can be helpful in alcoholism. Acamprosate has been available for several years, though only recently in the USA. We also have naltrexone, although in countries where it is available it is not always officially licensed for treating both alcoholism and opiate abuse. The imminent release of the first licensed long-acting depot naltrexone preparation (Garbutt et al 2005) is eagerly awaited in the belief that solving the compliance problem will reap dividends for the treatment community as well as the manufacturers. However, the third important fact is that we are now starting to see the results of studies comparing supervised disulfiram with one or both of these alternatives and they do not compare well even when they too are supervised. The first study - a small one - showed that naltrexone had no useful effect in patients who abused both alcohol and cocaine but SDT considerably reduced the consumption of both drugs. (Carroll and Ziedonis 1993) Its effectiveness was confirmed in a larger study in 1998 which incidentally and unexpectedly showed that SDT was significantly useful in cocaine abuse even when alcohol abuse was not an issue. (Carroll et al)

\section{DISULFIRAM IS MORE EFFECTIVE THAN PSYCHOTHERAPY.}

The study also compared various types of psychotherapy - cognitive-behavioural (CBT) and Twelve-Step facilitation (TSF) - with ordinary clinical management (CM) - ie minimal psychotherapy - with and without SDT. (Carroll et al, 1998) Subjects assigned to SD were retained in treatment significantly longer than those assigned to no medication (8.4 versus 5.8 weeks, p<0.05). Interestingly, the psychotherapy component had little effect on treatment retention and no significant differences between the two types of psychotherapy were found. "Effect sizes for disulfiram compared with no medication on duration of abstinence from cocaine, alcohol and both were, respectively, $0.42,0.68$ and 0.46 ." In contrast, "Effect sizes for the active psychotherapies compared with $\mathrm{CM}$ on duration of abstinence were 0.16 for cocaine, 0.11 for alcohol and 0.18 for both cocaine and alcohol." Effect size indicates the relative specific contribution of one particular component of a treatment programme 
relativa de un componente particular de un programa de tratamiento en relación con el resultado final, y los tamaños de efectos mayores son mejores que los más pequeños.

Algunas autoridades llevan tiempo reconociendo la eficacia del SDT. De hecho, William Miller lo incluye en su lista breve de intervenciones eficaces demostradas desde finales de los ochenta (Millar, 1989; Millar, 1992) En el año 2003, la publicación de una revisión tipo Cochrane del Consejo Sueco de Evaluación Tecnológica en Sanidad indicó que el tamaño medio de efectos para naltrexona y acomprasato eran bastante moderadas, de 0.28 y 0.26 respectivamente, frente al 0.53 del TSD. (Berglund et al, 2003; Berglund y Johansson, 2003)

\section{EL DISULFIRAM FRENTE A LA NALTREXONA Y EL ACOMPRASATO}

En el año 2004 se publicó por primera vez un estudio aleatorio controlado que comparaba el uso supervisado del naltrexona y de disulfiram en alcoholismo puro. En él se señalaba que el TSD era sin duda más eficaz, aunque -misteriosamente- los pacientes bajo naltrexona mostraban unos niveles de ansia por la sustancia menor (De Sousa y De Sousa, 2004). Las diferencias no eran solamente significativas en el aspecto estadístico; eran realmente sorprendentes e importantes desde el punto de vista clínico. Después de 12 meses, cerca del doble de los pacientes con disulfiram se encontraban libres de recaídas (86\%) frente a los tratados con NTX $(44 \%)(p=0.0009)$. El tiempo que pasaba hasta la primera recaída de un consumo abusivo de alcohol era más largo en los pacientes tratados con disulfiram (119 días frente $63 p=0.020$ ). La gamma-glutamyl transpeptidasa (GGT) descendía de una manera más significativa que en el grupo tratado con NTX.

Los mismos autores llevaron a cabo un estudio similar de comparación entre el disulfiram y el acamprosato, con la diferencia de que esta vez la duración fue de ocho en vez de doce meses. Los resultados obtenidos fueron muy similares. Al finalizar el ensayo, se mantenía contacto con 93 de los 100 pacientes. La recaída (considerada como el consumo de más de 5 tomas de 40 gramos de alcohol en un día) se había producido a los 123 días de media en pacientes tratados con disulfiram frente a los 71 de los casos con acamprosato $(P=$ 0.0001). Un ochenta y ocho por ciento de los pacientes con disulfiram seguían sin beber frente al $46 \%$ de los que habían utilizado acamprosato $(p=0.0002)$. Sin embargo, como ocurría en el estudio de naltrexona, los pacientes asignados a acamprosato tenían una ansiedad menor que los de tratados con disulfiram $(p=0.002)$. Actualmente se está realizando en Helsinki un estudio aleatorio similar comparando el disulfiram con el naltrexona y el acomprasato (de manera independiente), esperándose sus resultados a lo largo del año 2006. to the overall outcome and bigger effect sizes are better than smaller ones.

Some authorities have long recognised the effectiveness of SDT. Indeed, William Miller has included it in his short list of demonstrably effective interventions since the late 1980s. (Miller 1989; Miller 1992) In 2003 the publication of a Cochranetype review from the Swedish Council on Technology Assessment in Health Care (SBU) noted that average treatment effect sizes for naltrexone and acamprosate. in alcoholism were a rather modest 0.28 and 0.26 respectively, against 0.53 for SDT. (Berglund et al, 2003; Berglund \& Johansson 2003)

\section{DISULFIRAM vs NALTREXONE OR ACAMPROSATE}

2004 saw the first published randomised controlled study comparing supervised naltrexone and supervised disulfiram in pure alcoholism. It showed that SDT was significantly more effective, even though - intriguingly - the naltrexone patients reported somewhat lower craving levels. (De Sousa and De Sousa, 2004) The differences were not just statistically significant; they were really striking and clinically important. After 12 months, nearly twice as many patients were relapsefree on disulfiram (86\%) as on NTX (44\%) $(p=0.0009)$ Survival time until the first relapse to heavy drinking was longer with disulfiram ( 119 vs 63 days $p=0.020$ ); and gamma-glutamyl transpeptidase (GGT) fell significantly $(p=0.038)$ more than in the NTX group.

The same authors carried out a similar study comparing disulfiram and acamprosate, except that it lasted eight months instead of twelve. It produced very similar results. At the end of the trial, 93 of 100 patients were still in contact. Relapse (the consumption of $>5$ drinks $/ 40 \mathrm{~g}$ of alcohol in one day) occurred at a mean of 123 days with disulfiram compared to 71 days with acamprosate $(P=0.0001)$. Eighty-eight per cent of patients on disulfiram remained abstinent compared to $46 \%$ with acamprosate $(p=0.0002)$. However, as with the naltrexone study, patients allocated to acamprosate had lower craving than those on disulfiram ( $p=0.002)$. A similar randomised study comparing disulfiram with both naltrexone and acamprosate (separately) is under way in Helsinki and the results are expected some time in 2006. 


\section{UN CASO DESAFIANTE}

La importancia del disulfiram no sólo radica en su superioridad frente a la naltrexona o al acamprosato o en su mayor eficacia demostrada como componente de un paquete de tratamiento que muchos de los tratamientos psicológicos, como ha señalado no sólo Carroll, sino también el conocido, pero muchas veces malinterpretado, estudio de Azrin et al. (1982). Imaginémonos la siguiente situación -seguro que familiar para cualquier especialista con experiencia en alcoholismo-. Un hombre de mediana edad nos visita. No es la primera vez que ha solicitado ayuda y ya ha pasado por todas las alternativas de tratamiento no farmacológico, además de haber estado ingresado en un establecimiento de rehabilitación en un par de ocasiones. Por desgracia, nunca ha conseguido mantenerse abstemio o tener un consumo controlado de la bebida durante un periodo significativo de tiempo. Puede tener un puesto de responsabilidad como ingeniero, gestor o médico, pero puede ser también trabajador de una fábrica. El hecho importante es que todavía cuenta con un puesto de trabajo o puede acceder a uno, sin haber caído aún en los continuos abandonos próximos o propios de la marginalidad social. Otro hecho igualmente importante es que aún cuenta con el apoyo de su familia, sus jefes y sus amigos no alcohólicos -si es que cuenta con alguno-, pero se encuentra frente al peligro real de perderlos. Si esto ocurre, tendrá más penas que ahogar por lo que el tratamiento tendrá aún menos posibilidades de finalizar con éxito. Realmente, se encuentra frente a su última oportunidad y está llamando a tu puerta y te está pidiendo a ti una vez más ayuda para resistirse a la tentación -que es la razón principal de la mayor parte de los tratamientos (Brewer, 1989)-. Él sabe que si vuelve a tener una recaída durante el próximo año, todo el mundo le abandonará y que su vida se convertirá en algo sucio, burdo y, con toda probabilidad, también breve. Y esto también lo sabes tú.

En este caso la cuestión no radica en si debes añadir naltrexona o acomprasate al conjunto de su tratamiento, productos que posiblemente ya ha recibido. Es obvio que necesita toda la ayuda que se le pueda ofrecer. No; la cuestión es porque no le darías tú a este hombre desesperado la medicación y la administración supervisada que ha mostrado claramente tener un efecto muy poderoso incluso en casos tan malos o peores que éste- por ejemplo, incluso en casos tan desesperados que les ha llevado a vivir en barrios marginales (Bourne 1966; Haynes 1979)-. Es más, un paquete de medicación que, administrado de una manera eficaz, no ha tenido jamás resultados negativos en las pruebas clínicas realizadas, al contrario que lo que ocurre con naltrexona y acamprosato, ambos con varios ejemplos de resultados negativos y muchos más con unos beneficios específicos reales modestos o marginales incluso en los casos con una elevada cumplimiento médico, como en

\section{A CHALLENGING CASE.}

The importance of disulfiram is not only a matter of its superiority to naltrexone or acamprosate: or of its demonstrablygreater effectiveness, as one component of a treatment package, than many psychological treatments, as shown not only by Carroll but also in the well-known but often misinterpreted study of Azrin et al (1982). Imagine the following situation - one that ought to be familiar to any experienced alcoholism specialist. A man in his forties consults you. It is certainly not the first time he has sought help and he has had all the usual non-pharmacological treatment options as well as a couple of periods in a residential rehabilitation establishment. Unfortunately, he has never managed abstinence or controlled drinking for long. He may have a responsible job in engineering, management or medicine, but he could equally be a factory worker. The important thing is that he is still employed or employable and has not yet joined the permanent drop-outs on or near the margins of society. Equally important, he still has support from his family, his employers and - if he has any - his nonalcoholic friends, but he at serious risk of losing all of them. If that happens, he will have even more sorrows to drown and treatment will have even less chance of success. Truly, he is drinking at the last chance saloon but he knocks on your door and he asks you to try once more to help him resist temptation - which is what most treatment involves. (Brewer, 1989) He knows that if he relapses again within the next year, everyone is quite likely to give up on him and that his life would then become nasty, brutish and quite possibly short as well. You know that too.

The question here is not whether you should add naltrexone or acamprosate to his treatment package, if he hasn't already had them. He obviously needs all the help he can get. No; the question is why would you not offer this desperate man the medication and the supervised administration that have consistently been shown to have a powerful effect even in cases just like this or even worse - ie even seemingly hopeless cases who have already got as far as Skid Row (Bourne 1966; Haynes 1979). A medication package, furthermore, that has never given negative results in clinical trials when efficiently administered, unlike naltrexone and acamprosate, both of which have produced several negative results and many more with only modest or marginal real and specific benefits even when medication compliance is high, 
el caso de las inyecciones depot de naltrexona (Garbutt et al. 2005).

\section{EFECTOS PSICOLÓGICOS DEL TRATAMIENTO DE DISULFIRAM}

El hecho de que el disulfiram se describa muchas veces como un "agente aversivo"', ha tenido como consecuencia que el tratamiento con disulfiram se haya considerado en gran medida una variedad de terapia de aversión. En realidad el disulfiram es un agente disuasorio que reprime la bebida de manera similar y con igual eficacia que cuando reducimos la velocidad de nuestro automóvil al descubrir cámaras de velocidad o al ver a un policía por el espejo retrovisor. No es necesario que nos detengan o sufrir la reacción del disulfiram al alcohol para evitar refrenar el acto en sí, aunque estas experiencias pueden reforzar la acción. En términos de comportamiento, el disulfiram puede ser también considerado como un antagonista o un "previsor de respuesta", pero es por igual importante el hecho de que hace más fácil la exposición a momentos y situaciones normales que pueden llevar al consumo de alcohol. Ello se consigue permitiendo que los pacientes lleven una vida normal con mayor - o en todo caso, mucho mayor - facilidad, lo que significa estar expuestos a situaciones cotidianas relacionadas con la bebi$\mathrm{da}$, sin que realmente consuman alcohol. Las primeras veces puede resultar difícil (aunque muchos pacientes se sorprenden de lo viable que puede ser), pero con la práctica llega a ser muy llevadero. Este proceso se ha comparado con el aprendizaje, generalmente rápido, de un nuevo idioma en un entorno en el que uno está privado de personas de su misma lengua materna - un escenario que cualquier buena escuela de idiomas organiza con facilidad en un curso de inmersión (Brewer y Streel, 2003)-

Como en otros casos de intervenciones eficaces contra el alcoholismo, es absolutamente necesario que el tratamiento de TSD se mantenga suficiente tiempo hasta conseguir reemplazar los hábitos antiguos y dañinos por otros nuevos y más positivos. Ello puede llevar desde unos pocos meses hasta unos cuantos años en el caso de recaídas recurrentes en tratamientos, pero algunos programas incorporan el TSD durante largos periodos como parte de un programa de completa rehabilitación externa dentro del modelo del "refuerzo comunitario". Los resultados publicados resultan muy alentadores con lo que se considera normalmente material terapéutico poco prometedor (Krahl, 2004) cuyo programa denominado "GOAL" (Objetivo) es la abreviatura de Grupo Orientado de tratamiento apoyado por Antabus a largo plazo. Este autor señala que la mayor parte de estos pacientes ya habían recibido anteriormente acamprosato, además de haber estado en tratamiento hospitalario previo en una media de 380 as with depot injections of naltrexone (Garbutt et al 2005).

\section{PSYCHOLOGICAL EFFECTS OF DISULFIRAM TREATMENT.}

Because disulfiram is often described as 'an aversive agent', disulfiram treatment is still widely regarded as a variety of 'aversion therapy. In reality, disulfiram is a deterrent and it deters drinking in just the same way, and just as effectively, as speed cameras or seeing a police car in your driving mirror deter speeding. You don't have to be arrested, or to experience the Disulfiram-Alcohol Reaction, to be deterred, though either experience is reinforcing. In behavioural terms, disulfiram can also be viewed as an antagonist or 'response-preventer' but just as importantly, it facilitates exposure to cues and situations that normally lead to drinking. It does this by making it easy - or at any rate, much easier - for patients to lead an ordinary life, which means exposing themselves to ordinary drink-related cues, without actually drinking alcohol. They may find it doesn't come easily at first (though many patients are surprised at how easy it can be) but it gets easier with practice. This process has been compared to the rapid learning of a foreign language when circumstances deprive you of people who speak your usual one - a situation which any good language school will happily create for you in an 'immersion' course. (Brewer and Streel 2003)

Clearly, like all effective alcoholism interventions, SDT needs to be continued for long enough for old, unhelpful habits to have a chance of giving way to new and better ones. This can take anything from a few months to a few years in the case of recurrent treatment failures but some programmes incorporate SDT for long periods as part of a comprehensive outpatient rehabilitation programme on the 'Community Reinforcement' model. Published results are very encouraging for what is normally viewed as very unpromising therapeutic material (eg Krahl 2004) whose programme title 'GOAL' is an abbreviation for Group Orientated Antabus-supported Long-term treatment. He makes the point that most of these patients had previously received acamprosate as well as a mean of 380 previous in-patient treatment 
días. A pesar de todo solo un 29\% de los 42 pacientes abandonó el tratamiento.

El conseguir, quizás por primera vez, mantenerse abstemio durante dos o tres meses en un entorno social normal (como oposición a una clínica residencial donde uno se mantiene protegido de las tentaciones habituales de consumo de alcohol) puede revelar la existencia de problemas psicológicos o psiquiátricos que podrían merecer un tratamiento incluso en el caso de que el alcohol no hubiera sido nunca un problema. Muchas veces, estos problemas sólo pueden ser identificados, y no digamos evaluados y tratados con precisión, una vez se ha superado el síndrome de abstinencia fisiológico, psicológico y social consecuencia del proceso de abandono del alcohol.

\section{SI ES TAN BUENO, ¿PÓROUE NO SE UTILIZA MÁS?}

El disulfiram es una droga desarrollada desde hace tiempo y, por lo tanto, sin una patente protegida. Ello le hace comparativamente más barata y generalmente está comercializada por fabricantes de drogas "genéricas" que realizan poca publicidad o investigación. Frente a lo que ocurre con la naltrexona y el acamprosato, existen muy pocos estudios de TSD que hayan recibido financiación por parte de los fabricantes de disulfiram. Teniendo en cuenta las críticas que han acusado y acusan a la investigación apoyada por la industria, este hecho debería reforzar la credibilidad de los contundentes resultados beneficiosos que se obtienen con los estudios sobre TSD. Por el contrario, la prontitud con la que la industria farmacéutica está dispuesta a financiar los estudios con naltrexona o acamprosato significa que los investigadores y departamentos en busca de proyectos y financiación estén mucho más dispuestos a estudiar estos productos que el disulfiram. Este desequilibrio tiene que ser reconducido.

Normalmente se exagera el miedo a la hepatotoxicidad del disulfiram y a otros efectos colaterales. En realidad son casos raros e idiosincrásicos probablemente relacionados con una sensibilidad previa al níquel (Berglund, 1995; Brewer y Hardt, 1999). Generalmente se produce un caso sobre 25.000 pacientes al año (Poulsen, 1992) y la recuperación es automática si se deja de suministrar disulfiram ante los primeros síntomas. Los casos de muerte por una reacción de disulfiramalcohol también son extremadamente raros (Chick y Brewer, 1999). Las advertencias a los pacientes de que eviten utilizar perfumes o lociones para el afeitado que contengan alcohol son otro ejemplo de esta actitud alarmista, ya que la única consecuencia posible es un enrojecimiento local y transitorio de la piel. De hecho, la aplicación deliberada de alcohol en la piel de pacientes que se encuentran tomando drogas sensibles al mismo es una de las vías para confirmar que se está suministrando una dosis adecuada. Si no existe reacción local, days. Yet only $29 \%$ of 42 patients withdrew from treatment.

The achievement, perhaps for the first time, of a two or three months of abstinence in the ordinary community (as opposed to a residential clinic where you are shielded against ordinary alcoholic temptations) may reveal the existence of significant psychological or psychiatric problems that would merit treatment even if alcohol had never been a problem. Often, such problems can only be identified, let alone properly assessed and treated, when the social, psychological and physiological fall-out from the withdrawal process has settled somewhat.

\section{IF IT'S SO GOOD, WHY ISN'T IT USED MORE?}

Disulfiram is an old drug, long out of patent protection. It is thus comparatively cheap and is often marketed by manufacturers of 'generic' drugs who do little advertising or research. In contrast to naltrexone and acamprosate, few SDT studies in the last thirty years have received any funding from disulfiram manufacturers. Given the criticisms that can be and have been levelled at industry-sponsored research, this fact should reinforce the credibility of the overwhelmingly positive outcomes in SDT studies. Conversely, the ready availability of pharmaceutical industry funding for naltrexone and acamprosate research means that researchers and departments looking for projects and funding are much more likely to study naltrexone or acamprosate than disulfiram. This imbalance should be reversed.

Fears of disulfiram hepatotoxicity and other side effects are commonly exaggerated. It is rare and idiosyncratic and probably related to previous nickel sensitisation (Berglund 1995; Brewer \& Hardt 1999). There is about one case in 25,000 patient years (Poulsen, 1992) and if disulfiram is stopped at the first signs, recovery is invariable. Death from the disulfiramalcohol reaction also seems to be extremely rare. (Chick \& Brewer, 1999) Advising patients to avoid applying alcohol-containing perfumes or after-shave lotions to the skin is a common example of alarmist attitudes since the only possible consequence is a transient localised reddening of the skin. Indeed, deliberately applying alcohol to the skin of patients taking alcoholsensitising drugs is a simple way of confirming that 
significará que la droga no se está dando correctamente (Yamauchi et al. 2000).

Otras razones para la baja utilización del TSD se encuentran en la ética antimedicación de muchos de los grupos de Alcohólicos Anónimos (AA) y a la simple ignorancia de las publicaciones. Aunque el psicoanálisis es una tendencia agotada en muchos países, su influencia residual sigue llevando muchas veces a la búsqueda de "problemas ocultos", muchos de los cuales desaparecen con sorprendente rapidez si se abandona el consumo del alcohol. Finalmente, como ya ha sido señalado por autoridades como Miller y Hester (1986), e incluso por simpatizantes de grupos de AA como Mathew et al. (1994), el énfasis que ponen muchas clínicas de los Estados Unidos y otros países en realizar rentables tratamientos hospitalarios de varias semanas llevados a cabo principalmente por expacientes mal pagados y entrenados exclusivamente en la ideología de los grupos de AA, van en detrimento de la aplicación de programas de tratamiento racionales, efectivos, flexibles y económicos. Esta situación puede ayudar a explicar los sorprendentes resultados de una investigación que ha revelado que los médicos especializados en adicción en Estados Unidos prescriben disulfiram o naltrexona a menos de un $15 \%$ de sus pacientes alcohólicos. (Mark et al., 2003)

El disulfiram puede ser prescrito junto con ACP o NTX y parece evidente que mejora la eficacia del ACP (Besson et al., 1998). Más importante es el hecho de que pueda añadirse a una mezcla de metadona en el caso de que el abuso del alcohol amenace con sabotear el tratamiento de mantenimiento con metadona, reduciendo de una manera notable y significativa el nivel de la bebida (Liebson et al., 1973).

Aunque se mantiene que no es popular entre los pacientes, Sereny et al. (1986) mostraron que el TSD era aceptado por un 95\% de alcohólicos, pacientes de buenos tratamientos convencionales, con tres recaídas. Al menos, el TSD puede ofrecer a estos pacientes la primera experiencia de un periodo significativo de abstinencia, durante el cual podrán aplicarse con mayor efectividad otros componentes del tratamiento (por ejemplo, el psicosocial). En algunos casos, solamente se necesita un tratamiento con TSD a largo plazo, que deberá continuarse por un periodo de hasta 15 años (Dandelot y Dupuis 1979; Brewer, 1993). Es más habitual, que tras un periodo de uno o dos años con TSD acompañado de una terapia de apoyo, la mayoría de los pacientes se acostumbren a una "Abstinencia Antagonista Asistida" y puedan incorporar la abstinencia en su repertorio cognitivo y de comportamiento sin disulfiram. En algunos casos, tras un periodo de abstinencia se puede llegar con éxito a un consumo controlado de la bebida (Brewer, 1996). Mientras tanto, la clara superioridad del TSD debe convertirle en la primera opción de tratamiento para pacientes cuyos problemas sociales, de vivienda, legales, financieros, de pareja o médicos the dose is adequate. If it is not adequate, there will be no local flush. (Yamauchi et al. 2000)

Other reasons for the under-use of SDT include the anti-medication ethos of many Alcoholics Anonymous (AA) groups and simple ignorance of the literature. Although psychoanalysis is a spent force in many countries, its residual influence often leads to a search for alleged "underlying problems", many of which disappear with amazing rapidity if drinking ceases. Finally, as has been pointed out by authorities such as Miller \& Hester (1986), and even by AA sympathisers such as Mathew et al (1994) the emphasis in many clinics in the US and elsewhere on several weeks of profitable inpatient treatment, delivered largely by poorly paid ex-patients trained exclusively in AA ideology, discourages the development of rational, effective, flexible and cost-effective treatment programmes. This may be one explanation for the surprising results of a survey which revealed that US addiction physicians prescribed disulfiram or naltrexone for fewer than $15 \%$ of their alcoholic patients. (Mark et al 2003)

Disulfiram can be prescribed together with ACP or NTX and certainly seems to improve the effectiveness of ACP (Besson et al 1998). More importantly, it can be added to methadone mixture when alcohol abuse threatens to sabotage methadone maintenance treatment, the reduction in drinking being both significant and striking (Liebson et al 1973)

Though allegedly unpopular with patients, Sereny et al (1986) showed that SDT was accepted by $95 \%$ of alcoholics who had relapsed three times despite good conventional treatment. At the very least, SDT can give such patients their first experience of a significant period of abstinence, during which other (eg psychosocial) components of treatment can be more effectively deployed. In some cases, long-term SDT is the only treatment required and it has been continued for as much as fifteen years. (Dandelot and Dupuis 1979; Brewer, 1993) More usually, after a year or two of SDT and supportive therapy, most patients seem to accustom themselves to 'Antagonist-Assisted Abstinence' and can then incorporate abstinence into their normal cognitive and behavioural repertoire without disulfiram. In some cases, successful controlled drinking can follow such a period of abstinence. (Brewer, 1996) Meanwhile, the clear superiority of SDT should make it the first treatment consideration for patients whose social, housing, legal, financial, marital or medical problems 
pueden empeorar rápidamente -haciendo, por lo tanto, cualquier tratamiento más difícil- si tienen una recaída al poco tiempo. Los pacientes que, encontrándose en esta situación, pidan ayuda pero se nieguen a utilizar el TSD, estarán mostrando que no quieren o no intentan realmente dejar de beber. En este caso, el terapeuta $-\mathrm{y}$ quizás también la familia del paciente- pueden abandonar conscientemente el tratamiento.

\section{REFERENCIAS / REFERENCES}

Azrin NH, Sissons RW, Meyer RJ, y Godley M. Alcoholism treatment by disulfiram and community reinforcement therapy. J Behaviour Therapy Exp Psychiat 1982; 13: 105-12.

Berglund M., Johansson B. A. The SBU Report on Treatment of Alcohol and Drug Problems. In: Maintenance Treatment of Heroin Addiction, Waal $\mathrm{H}$ \& Haga E (Eds), Cappelen Akademisk Forlag, Oslo, pp 76-90, 2003.

Berglund M, Thelander S, Salaspuro M, Franck J, Andréasson S, Öjehagen A. Treatment of Alcohol Abuse: An Evidence-Based Review. Alcoholism: Clinical and Experimental Research, 27:1645-1656, 2003.

Besson J, Aeby F, Kasas A et al. Combined efficacy of acamprosato and disulfiram in the treatment of alcoholism: a controlled study. Alcoholism - Clinical and Experimental Research 1998; 22:573-579.

Bourne PG, Alford JA y Bowcock JZ. Treatment of skid-row alcoholics with Disulfiram Quarterly Journal of Studies on Alcohol 1966; 27:42-48.

Brewer C y Smith J. Probation-linked supervised disulfiram in the treatment of habitual drunken offenders: results of a pilot study. British Medical Journal 1983; 287: 1282-3.

Brewer $\mathrm{C}$. How effective is the standard dose of disulfiram? A review of the disulfiram-alcohol reaction in practice. British Journal of Psychiatry 1984; 144: 200-202.

Brewer C. Resisting temptation: a psychological analysis. British Journal of Addiction: 1989; 84: 1371-2.

Brewer C. Controlled trials of Antabuse in alcoholism: the importance of supervision and adequate dosage. Acta Psychiatrica Scandinavica (Supplement) 1992;369:5158.

Brewer C. Long-term, high-dose disulfiram in the treatment of alcohol abuse. Br J Psychiat 1993; 163: 687-9.

Brewer $C$. Using disulfiram to maintain controlled drinking: A case report with a 14-year follow-up. Addiction Research 1996; 3: 231-235.

Brewer C y Hardt F. Preventing disulfiram hepatitis in alcohol abusers: inappropriate guidelines and the significance of nickel allergy. Addiction Biology 1999; 4: 303-308. would rapidly become much worse (and thus make treatment even more difficult) if they had an early relapse. If patients in this situation claim to want help but refuse SDT, it can only be because they do not actually want or intend to stop drinking. In that case, the therapist - and perhaps the patient's family as well - can disengage with a clear conscience.

Brewer C, Meyers RJ, Johnsen J. Does disulfiram help to prevent relapse in alcohol abuse?: (Invited Review). CNS Drugs 2000; 14: 329-341.

Brewer C, Streel E. Learning the language of abstinence in addiction treatment: some similarities between relapse-prevention with disulfiram, naltrexona and other pharmacological antagonists and intensive 'immersion' methods of foreign language teaching. Substance Abuse, 2003, 24 157-173.

Carroll KM, Ziedonis D, O'Malley S et al. Pharmacologic interventions for abusers of alcohol and cocaine: a pilot study of disulfiram versus naltrexona. American Journal on the Addictions 1993; 2: 77-79.

Carroll KM, Nich C, Ball SA, McCance E. y Rounsaville B J. Treatment of cocaine and alcohol dependence with psychotherapy and disulfiram. Addiction 1998; 93, 713-728.

Chick $\mathrm{J}$ y Brewer C. National differences in disulfiram prescribing. Psychiatric Bulletin 1999; 23:335-9.

Chick J. Disulfiram: cautions on liver function; how to supervise. Addiction 2004, 99; 25-28.

Dandelot J-B y Dupuis M. L'Antabuse: ange ou demon? [review of disulfiram neuropathy] Le Concours Medical 1979: 101; 7666-73.

De Sousa A y de Sousa A. Naltrexona vs disulfiram A one year follow up of alcohol dependence treatment. Alcohol Alcohol. 2004 Nov-Dec; 39:528-31.

De Sousa A y de Sousa A. An open randomized study comparing disulfiram and acamprosato in the treatment of alcohol dependence. Alcohol Alcohol. 2005 NovDec;40:545-8.

Edwards G. Alcohol, the ambiguous molecule. London, Penguin. 2000.

Ehrenreich $\mathrm{H}$, Krampe $\mathrm{H}$. Does disulfiram have a role in alcoholism treatment today? Not to forget about disulfiram's psychological effects. Addiction 2004, 99; 25-28.

Fuller R, Branchey L, Brightwell D et al. Disulfiram treatment of alcoholism. J Am Med Assoc 1986; 256: 1449-55.

Fuller R. Disulfiram treatment of alcoholism (letter) J Am Med Assoc 1987; 257:927.

Fuller R, Gordis E. Does disulfiram have a role in alcoholism treatment today? Addiction 2004, 99; 21-24. 
Garbutt JC, Kranzler HR, O'Malley SS, Gastfriend DR, Pettinati HM, Silverman BL, Loewy JW, Ehrich EW; Vivitrex Study Group. Efficacy and tolerability of longacting injectable naltrexona for alcohol dependence: a randomized controlled trial. J Amer Med Assoc 2005 Apr 6; 293:1617-25.

Haynes SN. Contingency management in a municipally administered Antabuse program for alcoholics. Journal of Behaviour Therapy and Experimental Psychiatry 1973; 4: 31-32.

Johnsen J. y Morland. Depot preparations of disulfiram: experimental and clinical results. Acta Psychiatrica Scandinavica 1992; 86: 27-30.

Krahl W. GOAL - Group Orientated Antabuse-supported Long-term treatment. Poster presentation at ESBRA, Mannheim Sept 2004.

Liebson I, Bigelow G y Flame R. Alcoholism among methadone patients: a specific treatment method. American Journal of Psychiatry 1973; 130: 483-485.

Mark TL, Kranzler HR, Song X, Bransberger P, Poole V, Crosse S. Physicians' opinions about medications to treat alcoholism. Addiction. 2003 May;98(5):617-26.

Mathew RJ, Georgi J, Nagy P. Substance Abuse Treatment: Beyond the Minnesota Model. North Carolina Med J 1994; 55: 224-6.

Miller WR. The effectiveness of alcoholism treatment modalities: causes and consequences of alcohol abuse.
Hearings before the committee on governmental affairs, part III: US Senate. 1989:171-185.

Miller W. The effectiveness of treatment for substance abuse: reasons for optimism. Journal of Substance Abuse Treatment 1992; 9: 93-102.

Miller W y Hester R. In-patient alcoholism treatments: who benefits? Am Psychologist 1986; 41: 794-805.

Niederhofer $H$, Staffen W. Comparison of disulfiram and placebo in treatment of alcohol dependence of adolescents. Drug and Alcohol Review, 2003; 22: 2957.

Poulsen EH, Loft S, Andersen JR y Andersen M. Disulfiram therapy - adverse drug reactions and interactions. Acta Psychiatrica Scandinavica 1992;86:59-66.

Sereny G, Sharma V, Holt J, Gordis E. Mandatory supervised Antabuse therapy in an outpatient alcoholism program: a pilot study. Alcoholism: Clinical Experimental Research 1986; 10: 290-2.

Sun F, Tsuritani I, Yamada Y. Contribution of genetic polymorphisms in ethanol-metabolizing enzymes to problem drinking behavior in middle-aged Japanese men. Behav Genet. 2002 Jul; 32: 229-36.

Yamauchi M, Kimura T, Takeda K, Sakamoto K, Ohata M, Tabe T, Nakano K, Fujiwara S, Takao Y, Toda G. Ethanol patch test: a simple method for identifying the effectiveness of cyanamide in alcoholics. Alcohol Clin Exp Res. 2000 Apr; 24 (4 Suppl): 39S-42S. 